Original Research Paper

\title{
Assessment of the Elements of the Sudan Grass Cultivation Technology in the Zone of Dry Steppes
}

\author{
${ }^{1}$ Beybit Nasiyev, ${ }^{1}$ Nurbolat Zhanatalapov and ${ }^{2}$ Vladimir Shibaikin

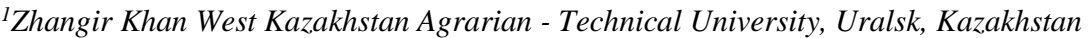 \\ ${ }^{2}$ Saratov State Vavilov Agrarian University, Saratov, Russia
}

\author{
Article history \\ Received: 13-11-2020 \\ Revised: 05-03-2021 \\ Accepted: 13-03-2021 \\ Corresponding Author: \\ Beybit Nasiyev \\ Zhangir Khan West \\ Kazakhstan Agrarian - \\ Technical University, Uralsk, \\ Kazakhstan \\ Email: veivit.66@mail.ru
}

\begin{abstract}
Sudan grass (Sorghum Sudanese (Piper.) Stapf) is the most productive, drought-resistant and promising crop for the dry-steppe zone of Western Kazakhstan. In this regard, in order to ensure an uninterrupted supply of livestock with feed raw materials, studies devoted to improving the elements of the Sudan grass cultivation technology in the conditions of the region are relevant. During the studies, various terms of sowing with the interval of 10 days were studied, along with the terms of collecting green fodder, haylage and hay in various development phases - before the ear formation phase, at the beginning of the ear formation phase and in the flowering phase, as well as the grazing conditions of using Sudan grass. The results of the scientific studies have shown that for the conditions of the region, it is important to choose the optimal terms for both sowing and harvesting. On average for the years of the research, the yield of the dry mass of Sudan grass at various terms of sowing has amounted to $17.88-22.06 \mathrm{c} / \mathrm{ha}$, while the highest productivity of $22.06 \mathrm{c} / \mathrm{ha}$ has been noted in the case of the early first term of sowing. In studying the terms of harvesting, a high yield of the dry mass of Sudan grass $(21.38 \mathrm{c} / \mathrm{ha}$ ) has been noted in the case of harvesting the grass stands in the phase of flowering. In the pasture conditions in the studied area, in the total over four grazings, Sudan grass has formed $16.97 \mathrm{c} / \mathrm{ha}$ of dry mass. The results of the study have been used by farmers for cultivating Sudan grass in the dry-steppe zone of Western Kazakhstan for providing full-fledged fodder for livestock breeding.
\end{abstract}

Keywords: Feed Value, Grazing Conditions, Sorghum Sudanese, Terms of Harvesting, Terms of Sowing

\section{Introduction}

The most important stage in creating a sustainable forage base in Western Kazakhstan is the mandatory cultivation of drought-resistant crops. Among this group of crops, Sudan grass - Sorghum Sudanese (Piper.) Stapf - is considered to be promising. By the peculiarities of its photosynthetic cycle, Sudan grass belongs to type C4, which determines its high productivity. In dry weather conditions, it ensures stable yields, compared to the traditional fodder crops, it grows quickly after harvesting and can be used for silage, haylage, grass flour and green mass (Bernáth et al., 2020).

This crop is characterized by high yield rates, rapid growth and resistance to droughts (Basaran et al., 2017; Mehmet, 2017). The productivity of Sudan grass is especially high in the periods with moisture reserves abundance (Dvořáčková et al., 2013). Along with the resistance to droughts, Sudan grass has a good ability to tolerate soil salinization (Ziki et al., 2019). The smaller leaf area, secondary roots and the wax coating on the surface make Sudan grass more resistant to droughts (Raiymbekov et al., 2017). Another advantage of this crop is its ability to grow faster, which makes it more competitive and capable of suppressing the weeds (Sowiński and Szydełko, 2011). This culture makes good use of the precipitation in the second half of the summer and, therefore, forms a significant above-ground mass. Sudan grass features a good recovery ability, bushiness and surpasses maize in terms of the daily growth, its good recovery ability makes three to four harvestings possible (Nasiyev, 2014). In terms of the nutrition value, it also ranks among the leaders. One kilogram of green mass contains 0.22 fodder units and up to 20 grams of 
digestible protein. In terms of the nutrients content, Sudan grass is superior to many other herbs and contains less fiber (Zherukov et al., 2006).

Sudan grass is a popular crop for the production of complete feeds in Europe and Asia (Nazli et al., 2014; Amaducci et al., 2016; Blanco et al., 2016; McIntosh et al., 2016). All the above advantages of Sudan grass depend on the proper choice of the sowing terms and terms of harvesting. Sudan grass belongs to the latesown crops. Sowing Sudan grass is best done after soil warming to $10-12^{\circ} \mathrm{C}$ at the depth of $10 \mathrm{~cm}$. In the case of early sowing into insufficiently warmed soil, germination of the seed material reduces to $40 \%$, the number of dead seeds increases, the period of survived seeds germination increases to 20-25 days and the seedlings turn out to be thinned. With that, delayed sowing of Sudan grass is not recommended, since in this case, the seeds fall into the already dry soil, which also inhibits their germination (Bondarenko and Kopyrin, 2015; Kapustin, 2019).

An important point is the choice of the term of sowing. The seeds start germinating at $5-8^{\circ} \mathrm{C}$ at the seeding depth. However, the optimal temperature for seed germination is $10-12^{\circ} \mathrm{C}$. When sown into the sufficiently warmed soil, the seedlings appear on the 5-7th day. The seedlings easily tolerate frosts down to $-2.0--2.5^{\circ} \mathrm{C}$. In cultivation for fodder purposes, there is a certain experience in sowing Sudan grass into the soil at $8-10^{\circ} \mathrm{C}$ at the seeding depth (Kshnyakin and Zozulin, 2014; Lukhmanova, 2019).

In Sudan grass cultivation, harvesting in the optimal terms is important. According to some scientists, it is recommended to harvest Sudan grass for green fodder and hay in the phase of booting (Carnevalli et al., 2006) and in the opinion of the others, harvesting should be done in the phase of ear formation (Zanini et al., 2012).

It should also be borne in mind that the time of the first harvesting has a significant effect on the aftermath harvest. In the case of harvesting in the phase of booting, the yield during the first harvesting is lower than that in the phase of ear formation, at the same time, the aftermath harvest is the highest in this case (Nasiyev, 2014). Kolomiets et al. (1999) recommend considering the varietal characteristics of Sudan grass in choosing the term of harvesting, noting that Sudan grass should be harvested at the beginning of the flowering phase.

Due to its recovery ability, Sudan grass is also a promising crop for grazing. When cultivated in the grazing conditions, the onset of the phenological phases and the duration of the vegetation season are of great practical importance, since these characteristics determine the time of practical use. The absence of photoperiodic induction was found by (Grigoriev, 1993) in various varieties of Sudan grass, which allowed adjusting the time of the plants reaching suitability for the use in grazing conditions for a specific soil-and-climatic zone.

Despite all the advantages, the acreage of Sudan grass in the dry-steppe zone of the Western Kazakhstan region remains small and its productivity is very low. The main reason is the lack of adaptive technologies for cultivation. For this reason, in order to increase the yield and feed quality, the Sudan grass sowing terms and terms of harvesting which would be optimal for the conditions of the dry-steppe zone of Western Kazakhstan should be chosen. Due to this, the goal was set to assess seeding and harvesting terms and use of Sudan grass in the grazing conditions for ensuring uninterrupted supply of fodder for livestock breeding.

\section{Methods}

The studies were performed at the experimental station of the Zhangir Khan West Kazakhstan AgrarianTechnical University (Uralsk, Republic of Kazakhstan). By the morphological traits of the genetic horizons of the profile and the agrochemical parameters of the arable layer, the soil of the experimental plot was characteristic of the dry-steppe zone of Western Kazakhstan.

The area of each plot was $50 \mathrm{~m}^{2}$. The experiment was repeated three times on randomly located plots. In the first experiment, three Sudan grass terms of sowing were studied. The first sowing was made when the soil temperature at the seeding depth reached $8-10{ }^{\circ} \mathrm{C}$, the second sowing was made 10 days after the first one and the third sowing was made 10 days after the second seeding.

In the second experiment, three terms of Sudan grass harvesting were studied: The first harvesting was made before the phase of ear formation, the second harvesting - at the beginning of the phase of ear formation and the third harvesting - in the flowering phase.

In the third experiment, the use of Sudan grass in the grazing conditions was studied. In the experiment, the zoned Sudan grass variety Brodskaya 2 was used.

The agricultural technology of cultivating Sudan grass was the one adopted for the dry-steppe zone of Western Kazakhstan. The main soil cultivation was carried out to a depth of 20-22 cm with STAVR PG-5 flat-cutter-subsoiler with simultaneous application of mineral fertilizers - ammonium nitrate $\left(\mathrm{NH}_{4} \mathrm{NO}_{3}\right)$ and double superphosphate $\left(\mathrm{Ca}\left(\mathrm{H}_{2} \mathrm{PO}_{4}\right)_{2}\right)$ - at a dose of $\mathrm{N}_{30} \mathrm{P}_{30}$. In winter, snow retention was carried out with SVU 2.6A units. In spring, before sowing, the soil was harrowed with BIG-3 harrows and two presowing cultivations were performed with KPE-3.8 cultivators. Sowing was carried out with SKP 2.1 seeder to a depth of 2-3 cm with a seeding rate of 1.5 million seeds per hectare. The green mass of the Sudan grass was harvested with KS-2.1 mower. (All-Russian Research Institute of Feed named after V.R. Williams, 2018). 
In the field experiments, accountings and observations of the onset of the phenological phases and the growth of Sudan grass were performed following the generally adopted methods (All-Russian Research Institute of Feed named after V.R. Williams, 2018).

The height of the plants was measured in the main phases of Sudan grass development: Tillering, booting, ear formation and flowering. The photosynthetic activity of Sudan grass was studied following the standard methodology (Nichiporovich, 1961).

Harvesting and yield accounting were made using the continuous method. When Sudan grass was used in the grazing conditions, the first grass stand grazing was performed by the method of simulation between the phases of tillering and booting. Subsequently, repeated grazings of Sudan grass stands were made when the pasture vegetative mass grew to a height of $40-50 \mathrm{~cm}$.

Based on the results of the chemical analysis of the green mass of Sudan grass, bioenergy assessment of the studied techniques was made following the adopted methodology (All-Russian Research Institute of Feed named after V.R. Williams, 2017). The results of the research were statistically processed by the method of variance analysis (Dospekhov, 2011). Statistical curves were built in the Statistica 6.0 application. The results of statistical data processing - Standard Deviation (SD), Standard Error (SE) and significance level (p-value)showed the reliability of these studies.

Over the years of the research, the growth and development of Sudan grass depended both on the cultivation techniques used and on the prevailing weather conditions during the vegetation season. In the experiments on studying the terms of sowing, the duration of the vegetation period after the first term of sowing in 2018 was 58 days, in 2019-56 days. After the second term of sowing, Sudan grass in 2018 formed the productive grass stand in 56 days and in 2019 -in 50 days. After the third term of sowing, Sudan grass reached the flowering phase in 2018 in 46 days and in 2019, the flowering phase of Sudan grass was reached 45 days after sowing. In 2018, with three sowing periods, the duration of the growing season was 1-3 days longer than the duration of Sudan grass development in 2019. In the variants of the terms of harvesting in 2018, the duration of the Sudan grass vegetation period was shorter by 4-8 days, compared to 2019 .

\section{Results}

The Biometric Parameters of Sudan Grass, Depending on the Terms of Seeding and Harvesting

Sudan grass growth and development were significantly influenced by the prevailing weather conditions during the vegetation season. In terms of the weather conditions, the most favorable ones for Sudan grass growth and development were in 2019. In June 2019, $40.2 \mathrm{~mm}$ of rain fell during the period of Sudan grass intensive growth and yield formation, which exceeded the multiyear data by $8.2 \mathrm{~mm}$. On the contrary, in June 2018, $6.2 \mathrm{~mm}$ of rain fell, which was less than the norm by $25.8 \mathrm{~mm}$. Besides, the year 2018 was not very favorable in terms of the temperature conditions. In June 2018, the average monthly air temperature was lower by $0.6^{\circ} \mathrm{C}$ than the norm and amounted to $19.8^{\circ} \mathrm{C}$. The cool weather in June 2018 inhibited Sudan grass growth and development.

Those weather conditions had a significant effect on the height of the plants. Higher plant height was noted in 2019. In the variants with different terms of sowing, Sudan grass height in 2019 ranged from 92.18 $\mathrm{cm}$ (the third term) to $103.50 \mathrm{~cm}$ (the first term). With that, the height of Sudan grass plants in the main phases of development depended on the weather conditions during the vegetation period. The average height of Sudan grass plants in the variants with three terms of sowing 2018 and 2019 revealed nonlinear development of the process.

Out of the terms of sowing, the minimum Sudan grass height was noted in the variants with the third term of sowing, i.e., 20 days after the first term of sowing. In studying the terms of harvesting, the height of the plants in 2019 was $62.05 \mathrm{~cm}$ (the first term) to $98.92 \mathrm{~cm}$ (the third term). However, decreased plant growth was noted in 2018 in all variants. With that, the lowest height of Sudan grass $(51.32 \mathrm{~cm})$ was noted in 2018 in the variant with the first term of harvesting before the phase of ear formation.

As one can see in Fig. 1, when early sowing (the first term) was used, the greatest plant height was achieved and in the variant with the first term of harvesting, the smallest plant height was noted before the phase of ear formation.

Approximately the same height of Sudan grass plants was noted in the variant with the third term of harvesting and in the variant with the first term of sowing. If Sudan grass sowing had been delayed to the third term, the plant height reduced and if harvesting had been delayed to the phase of flowering, the plant height increased.

The productivity of any crop is formed not only by the significant vegetative mass but also by the morphobiological features of the structure of individual organs. Important components of Sudan grass productivity are the foliage and the leaf area (Grigoriev, 1993; Zherukov et al., 2006).

As shown by statistical analysis, the leaf area and foliage of Sudan grass in the studies were stipulated by both the term of sowing and the term of harvesting.

The scattering diagrams for blocks A, B, C, D in Fig. 2 show the values for three variables on various terms of sowing and harvesting. 


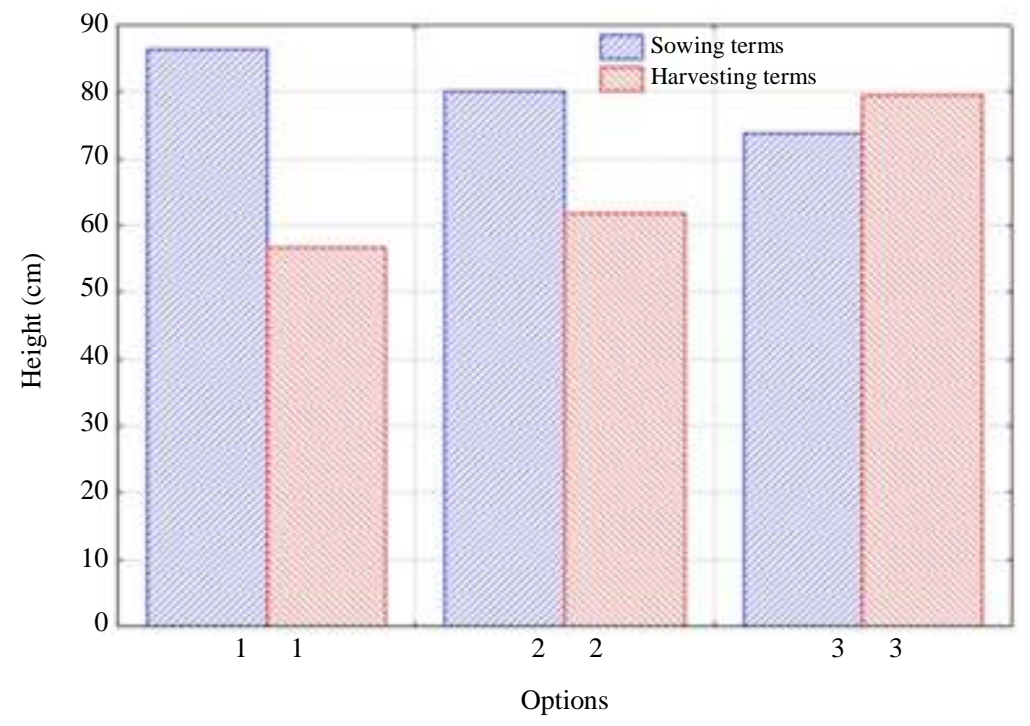

Fig. 1: The effect of the sowing and terms of harvesting on the height of Sudan grass, the average for 2018 and 2019 , cm. Terms of sowing: 1 - sowing at $8-10^{\circ} \mathrm{C}$ at the seeding term; 2 - sowing 10 days after the first term of sowing; 3 - sowing 10 days after the second term of sowing. Terms of harvesting: 1 - harvesting before the phase of ear formation; 2 - harvesting at the beginning of the phase of ear formation; 3 - harvesting in the flowering phase
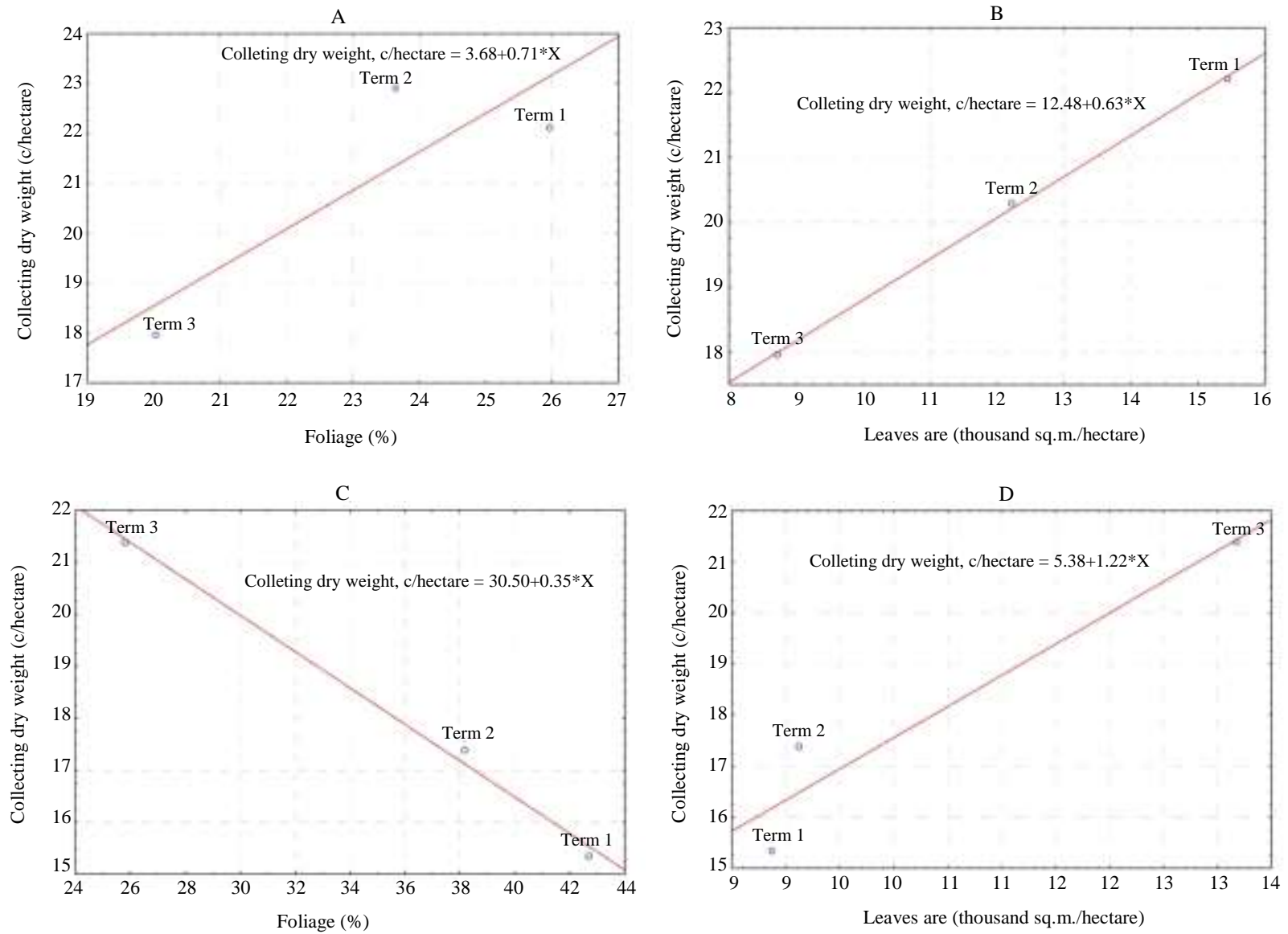

Fig. 2: The influence of the foliage and leaf area on the yield of the dry mass of Sudan grass in the case of various terms of sowing and harvesting, average for 2018, 2019: A - foliage in the case of various terms of sowing; B - leaf area in the case of various terms of sowing; $\mathrm{C}$ - foliage in the case of various terms of harvesting; D - leaf area in the case of various terms of harvesting 
By analyzing the diagrams by blocks, the authors determined the following relations between these two variables. For block A, it is possible to conclude that the foliage at various terms of harvesting had a positive effect on the leaf area. The effectiveness of interaction depended on the term of sowing. In terms of the rate of foliage to the dry weight yield, the first term of sowing was the best. In block B, the same relationship between the leaf area and the dry mass yield by the terms of sowing was observed. Block $\mathrm{C}$ shows the difference in the tendency of the term of harvesting influence from the other blocks. This diagram shows that the greatest effect of foliage was achieved on the third term of harvesting. For block D, an assumption can be made about the greatest effect of the leaf area on the yield of dry mass in the case of the third term of harvesting in the phase of Sudan grass flowering.

The analysis of the yield structure showed that the terms of sowing and harvesting had a significant effect on the indicator of product quality - the foliage of Sudan grass (the content of protein and other nutritional components of the yield). The foliage of Sudan grass is the most valuable part of the yield structure that determines the quality of the product. The studies revealed significantly higher foliage of Sudan grass in 2019 , compared to 2018. On average over the two years, high foliage $(25.98 \%)$ was noted in the case of the first term of sowing with the soil temperature of $8-10^{\circ} \mathrm{C}$ at the seeding depth. Delaying sowing reduces the foliage of Sudan grass to $20.04-23.65 \%$.

On average over the two years, the optimal foliage of Sudan grass was formed in the case of harvesting at an earlier term - before the phase of ear formation $(42.69 \%)$. Upon delaying the term of harvesting to the phases of ear formation and flowering, the number of leaves reduced to $25.31-38.17 \%$ due to the increased share of stems and panicles in the yield structure. On average over the two years of the studies, the largest area of Sudan grass leaves (15.44 thousand $\mathrm{m}^{2} / \mathrm{ha}$ ) was observed in the variant with the first term of sowing. The highest leaf area (13.18 thousand $\mathrm{m}^{2} / \mathrm{ha}$ ) was noted in the case of harvesting Sudan grass in the flowering stage. Delaying the terms of sowing and harvesting reduced the Sudan grass leaves area.

The degree of bushiness is also an important parameter of Sudan grass (Grigoriev, 1993; Zherukov et al., 2006). As shown by the data of the studies, the terms of sowing and harvesting have a direct effect on bushiness. On average over the two years of the studies, the highest degree of bushiness (4.1) was noted in the case of the first term of sowing, while the lowest (3.75) degree of bushiness was noted in the case of the late third term.

In the variants of studying the terms of harvesting, different degrees of Sudan grass bushiness were also noted. In the case of harvesting before the phase of ear formation, Sudan grass bushiness was 3.75 . In the case of harvesting at the beginning of the phase of ear formation, the number of Sudan grass sprouts was 3.85 per plant. With further delaying the term of harvesting until the flowering phase, the number of Sudan grass sprouts increased to 3.95 per plant.

\section{The Yield Rate and Forage Value of Sudan Grass, Depending on the Terms of Sowing and Harvesting}

The yield rate shows and integrates the effect of all the factors that have an effect on the plant during development and its value is always the result of a compromise between productivity and sustainability. The agronomic interpretation of plants' adaptability involves, according to (Zhuchenko, 1990; Golubinova, 2020), the use of environmental resources and resistance to abiotic and biotic stresses, which ensure a high index of the yield and its quality and consequently, the minimum consumption of assimilators for maintaining the permanence of the metabolic processes in the plants (Nasiyev et al., 2019).

As shown in Fig. 3 and 4, the average yield of the dry mass of Sudan grass over the two years of the studies significantly depended on the cultivation methods: The terms of sowing and harvesting.

Analysis of variance showed that the differences in means across groups were significant at the p-level $<0.09$.

Analysis of variance showed that the differences in means across groups were significant at the p-level $<0.14$.

The use of different terms of sowing and harvesting significantly altered the yield of dry mass.

In studying the terms of sowing and harvesting, the yield of dry mass was higher in 2019, compared to the values for 2018 .

Higher productivity values were noted in the case of the first term of sowing with the soil temperature of 8 $10^{\circ} \mathrm{C}$ at the seeding depth. On average for the two years, in this variant, the yield of dry mass was high and amounted to $22.06 \pm 1.42 \mathrm{c} / \mathrm{ha}$. Further delaying the term of sowing for 10 and 20 days significantly reduced the productivity of Sudan grass. The highest yield of the dry mass of Sudan grass was noted in the case of harvesting in the phase of flowering. On average for the two years, in the case of harvesting in the phase of flowering, the yield of dry mass was $21.38 \pm 3.27 \mathrm{c} / \mathrm{ha}$. In the case of harvesting before the phase of ear formation, Sudan grass productivity veraciously decreased.

The year and the methods of cultivation, including the terms of sowing and harvesting, have a significant effect on the yield of exchange energy and accumulation of fodder units by Sudan grass. Both in terms of exchange energy and in terms of accumulating fodder units, Sudan grass productivity was higher in 2019, compared to that in 2018. 
Table 1: The effect of the term of sowing on the forage value of Sudan grass in the zone of dry steppes of Western Kazakhstan, the average for 2018 and 2019

\begin{tabular}{|c|c|c|c|c|}
\hline \multirow[b]{2}{*}{ Sowing period option* } & \multicolumn{2}{|c|}{ Exchange energy yield, GJ/ha } & \multicolumn{2}{|c|}{ Harvesting of fodder units, c/ha } \\
\hline & SD & SE & SD & SE \\
\hline 1 & $21.56 \pm 1.39$ & 0.98 & $19.39 \pm 1.25$ & 0.89 \\
\hline 2 & $19.81 \pm 1.32$ & 0.93 & $16.83 \pm 1.11$ & 0.79 \\
\hline 3 & $17.51 \pm 0.71$ & 0.50 & $14.30 \pm 0.57$ & 0.40 \\
\hline
\end{tabular}

Remarks: $* 1$ - sowing at $8-10^{\circ} \mathrm{C}$ at the seeding term; 2 - sowing 10 days after the first term of sowing; 3 - sowing 10 days after the second term of sowing

Table 2: The effect of the term of harvesting on the forage value of Sudan grass in the zone of dry steppes of Western Kazakhstan, the average for 2018 and 2019

\begin{tabular}{llll}
\hline & Exchange energy yield, GJ/ha & Harvesting of fodder units, c/ha \\
Harvesting period option & SD & SE & SD \\
\hline Harvesting before ear formation phase & $15.89 \pm 2.41$ & 1.71 & $13.38 \pm 2.09$ \\
Harvesting at the beginning of ear formation phase & $17.36 \pm 2.53$ & 1.79 & $14.28 \pm 2.12$ \\
Harvesting in the phase of flowering & $21.04 \pm 3.38$ & 2.39 & $17.21 \pm 2.76$ \\
\hline
\end{tabular}

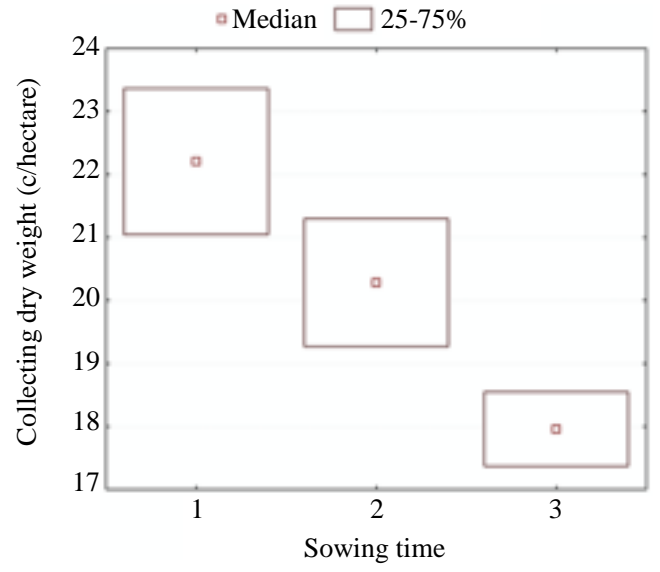

Fig. 3: The diagram of the dry mass of Sudan grass yield range depending on the term of sowing, c/ha (average for 2018 and 2019)

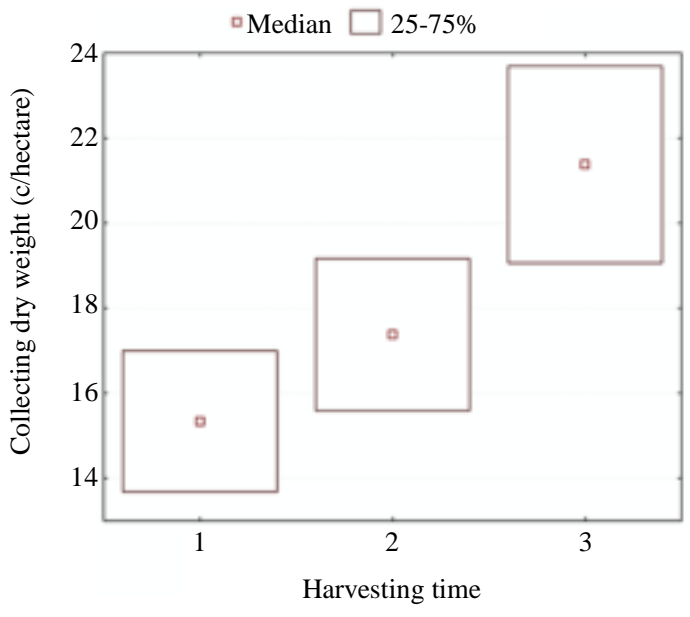

Fig. 4: The diagram of the dry mass of Sudan grass yield range, depending on the term of harvesting, c/ha (average for 2018 and 2019)
On average over the years of the studies, the highest yield of exchange energy $(21.56 \pm 1.39 \mathrm{GJ} / \mathrm{ha})$ and accumulation of fodder units $(19.39 \pm 1.25 \mathrm{c} / \mathrm{ha})$ was observed in the case of the first term of sowing with the soil temperature of $8-10^{\circ} \mathrm{C}$ at the seeding depth. Delaying the term of sowing reduced the feed value of Sudan grass. For instance, in the case of the third term of sowing, the yield of exchange energy decreased to $17.51 \pm 0.71 \mathrm{GJ} / \mathrm{ha}$ and the accumulation of fodder units to $14.30 \pm 0.57 \mathrm{c} /$ ha (Table 1$)$.

Analysis of variance of the data on the yield of exchange energy and the accumulation of fodder units by Sudan grass depending on the terms of sowing was performed $(\mathrm{p}=0.009)$, the statistically significant differences in means were noted at the p-level $<0.09$.

In the studies aimed at assessment of the terms of Sudan grass harvesting for the conditions of the dry-steppe zone of Western Kazakhstan in terms of the forage value, the most acceptable variant was harvesting in the phase of flowering. On average over the two years of the studies, the yield of exchange energy and the accumulation of fodder units in this variant were the highest, compared to the values in the case of the terms of harvesting in earlier phases, these rates were $21.04 \pm 3.38 \mathrm{GJ} / \mathrm{ha}$ and $17.21 \pm 2.76$ c/ha, respectively (Table 2 ).

Analysis of variance of the data on the yield of exchange energy and the accumulation of fodder units by Sudan grass depending on the terms of harvesting was performed $(\mathrm{p}=0.13)$, the statistically significant differences in means were noted at $\mathrm{p}<0.14$.

\section{The Pasture Conditions of using Sudan Grass}

One of the distinguishing properties of Sudan grass is the possibility of using this crop in the pastures. In using Sudan grass in the pasture conditions, its productivity is the main indicator of the economic value and efficiency of this crop (Nasiyev et al., 2019). 
Table 3: Productivity and fodder value of Sorghum sudanense for pasture mode, average for 2018, 2019, c/ha

\begin{tabular}{|c|c|c|c|c|c|c|}
\hline \multirow[b]{2}{*}{ Sequence of pasturing } & \multicolumn{2}{|c|}{ Dry weight yield, c/ha } & \multicolumn{2}{|c|}{ Exchange energy yield, GJ/ha } & \multicolumn{2}{|c|}{ Harvesting of fodder units, c/ha } \\
\hline & SD & SE & SD & SE & SD & SE \\
\hline 1 & $4.74 \pm 0.53$ & 0.37 & $4.93 \pm 0.55$ & 0.39 & $4.12 \pm 0.47$ & 0.33 \\
\hline 2 & $5.13 \pm 0.16$ & 0.12 & $5.33 \pm 0.16$ & 0.12 & $4.46 \pm 0.14$ & 0.10 \\
\hline 3 & $4.29 \pm 0.93$ & 0.66 & $4.45 \pm 0.68$ & 0.68 & $3.73 \pm 0.81$ & 0.57 \\
\hline 4 & $2.83 \pm 0.98$ & 0.69 & $2.93 \pm 0.71$ & 0.71 & $2.46 \pm 0.85$ & 0.60 \\
\hline Amount of 4 pasturings & $16.97 \pm 2.60$ & 1.84 & $17.64 \pm 2.69$ & 1.90 & $14.77 \pm 2.26$ & 1.60 \\
\hline
\end{tabular}

In the studies performed in 2018 and 2019, the yield of Sudan grass over the entire period of pasture use depended on the productivity of each grazing individually. On average for the two years, the yield of the dry mass of Sudan grass in the pasture conditions after one grazing was $4.74 \pm 0.53 \mathrm{c} / \mathrm{ha}$. After the second grazing, the yield of dry mass was $5.13 \pm 0.16 \mathrm{c} / \mathrm{ha}$ (Table 3 ).

The yield of the second grazing slightly exceeded that of the first one. This confirms the effect of the temperature on the Sudan grass growth rate. With that, the density of the plant stand in the case of the second term of sowing was inferior to that of the first one and the yield of green mass increased due to the increased weight of individual plants. After the third and the fourth grazings, further reduction of dry mass yield of Sudan grass was noted.

The yield of dry mass after the third and the fourth grazings was $4.29 \pm 0.93$ and $2.83 \pm 0.98 \mathrm{c} / \mathrm{ha}$, respectively.

The total productivity of Sudan grass in the pasture conditions on average for 2018 and 2019 was $16.97 \pm 2.60 \mathrm{c} / \mathrm{ha}$ for dry mass.

In the studies, the use of Sudan grass in the pasture conditions was also assessed in terms of its nutrition and energy value. The results of the analysis showed that on average over the two years of the studies, Sudan grass used in the pasture conditions provided a sufficient amount of forage mass with satisfactory fodder and energy properties. With that, the yield of fodder units, digestible protein and exchange energy was high after the first and the second grazings. Further, a decrease in the accumulation of nutrient and energy valuable properties was noted.

In total over four aftermath grazings, on average for 2018 and 2019 Sudan grass provided $14.77 \pm 2.26 \mathrm{c} / \mathrm{ha}$ of the fodder units with the yield of exchange energy of $17.64 \pm 2.69 \mathrm{GJ} / \mathrm{ha}$.

Analysis of variance of data on the dry mass yield, the yield of exchange energy and the accumulation of fodder units by Sudan grass in the pasture conditions was performed $(p=0.24)$, the statistically significant differences in means were noted at $\mathrm{p}<0.25$.

\section{Discussion}

In the research of scientists (Kshnyakin and Zozulin, 2014), the highest yield of fodder mass of Sudan grass
(27.2 $\mathrm{kg} / \mathrm{ha})$ under the conditions of Novosibirsk was obtained in the case of early sowing. In the studies of F.Kh. Lukhmanova (2019), carried out in Bashkiria, the dry mass yield of Sudan grass was $29.1 \mathrm{c} / \mathrm{ha}$ during the first sowing period. According to the research results, the most optimal terms for Sudan grass sowing were revealed: Soil temperature at the seeding depth should be $8-10^{\circ} \mathrm{C}$. On average over 2 years, the dry mass yield of Sudan grass amounted to $22.06 \pm 1.42 \mathrm{c} /$ ha, the yield of exchange energy - to $21.56 \pm 1.39 \mathrm{GJ} / \mathrm{ha}$, the yield of accumulated fodder units - to $19.39 \pm 1.25 \mathrm{c} / \mathrm{ha}$.

The research results allowed revealing the optimal terms for Sudan grass harvesting. The best period for harvesting of Sudan grass was in the flowering phase, when the yield of dry mass of Sudan grass amounted to $21.38 \pm 3.27 \mathrm{c} / \mathrm{ha}$ and the yield of fodder units was $17.21 \pm 2.76 \mathrm{c} / \mathrm{ha}$, which was also confirmed by the studies of (Kolomiets et al., 1999).

In the study by Grigoriev (1993), the highest productivity of Sudan grass was determined in the pasture conditions, which was confirmed by the results of current research. According to the results of analysis, in the conditions of the dry-steppe zone, the best productivity values of Sudan grass were revealed during the period of pasture use: Dry matter yield amounted to $16.97 \pm 2.60$ $\mathrm{c} / \mathrm{ha}$, the yield of fodder units - to $14.77 \pm 2.26 \mathrm{c} / \mathrm{ha}$ and the yield of exchange energy - to $17.64 \pm 2.69 \mathrm{GJ} / \mathrm{ha}$.

\section{Conclusion}

Sudan grass cultivation technology requires for correct selection of the terms of sowing and harvesting, as well as the conditions of its implementation.

Following the purpose of the research, the following elements of the Sudan grass cultivation technology have been selected:

- Sudan grass sowing should be performed with the soil temperature of $8-10^{\circ} \mathrm{C}$ at the seeding depth

- Sudan grass should be harvested at the beginning of the flowering phase

It is highly recommended to use Sudan grass in the pasture conditions at the beginning of summer in order to provide the farm animals with the full-fledged fodder during the period of its shortage. 
The introduction of elements of Sudan grass cultivation technology in the production process allowed reducing the cost of fodder by $15 \%$ and increasing the profitability of production by $18 \%$. The idea and research data serve as a prerequisite for the development of efficient technologies for cultivating Sudan grass outside Kazakhstan, in countries and regions with similar natural and climatic conditions.

\section{Acknowledgement}

The studies were performed within the program of grant funding by the Committee for Science of the Ministry of Education and Science of the Republic of Kazakhstan for project AR05130172 "Development of Adaptive Technologies for Cultivating Forage and Oilseed Crops in the Conditions of Western Kazakhstan".

\section{Author's Contributions}

All authors contributed equally in this paper.

\section{Ethics}

This article is original and contains unpublished material. The corresponding author confirms that all other authors have read and approved the manuscript and no ethical issues have been involved.

\section{References}

All-Russian Research Institute of Feed named after V.R. Williams, (2018. Methodological instructions conducting field experiments with feed crops. Moscow, pp: 35-74. https://www.vniikormov.ru/statji.php

All-Russian Research Institute of Feed named after V.R. Williams, (2017). Methodological recommendations on bioenergetic assessment of crop rotations and technologies for growing fodder cultures. Moscow, pp: 32-44. https://www.vniikormov.ru/statji.php

Amaducci, S., Colauzzi, M., Battini, F., Fracasso, A., \& Perego, A. (2016). Effect of irrigation and nitrogen fertilization on the production of biogas from maize and sorghum in a water limited environment. European Journal of Agronomy, 76, 54-65. https://doi.org/10.1016/j.eja.2016.01.019

Basaran, U., Dogrusoz, M. C., Gulumser, E., \& Hanife, M. U. T. (2017). Hay yield and quality of intercropped Sorghum-Sudan grass hybrid and legumes with different seed ratio. Turkish Journal of Field Crops, 22(1), 47-53. https://doi.org/10.17557/tjfc.301834
Bernáth, S., Šiška, B., Paulen, O., Zuzulová, V., Pintér, E., Žilinský, M., \& Tóth, F. (2020). Grape Quality Parameters in Western Carpathian Region under Changing Climatic Conditions as Influenced by Drought. Journal of Ecological Engineering, 21(4). https://doi.org/10.12911/22998993/119796

Blanco, A., Salazar, M. J., Cid, C. V., Pereyra, C., Cavaglieri, L. R., Becerra, A. G., ... \& Rodriguez, J. H. (2016). Multidisciplinary study of chemical and biological factors related to $\mathrm{Pb}$ accumulation in sorghum crops grown in contaminated soils and their toxicological implications. Journal of Geochemical Exploration, 166, 18-26. https://doi.org/10.1016/j.gexplo.2016.01.020

Bondarenko, M. G., \& Kopyrin, V. I. (2015). Optimal terms of Sudan grass sowing for the forage. Bulletin of Agricultural Science of Kazakhstan, 12, 38-39. https://www.vetpress.ru/jour/article/view/1040

Carnevalli, R. A., Da Silva, S. C., Bueno, A. D. O., Uebele, M. C., Bueno, F. O., Hodgson, J., ... \& Morais, J. P. G. (2006). Herbage production and grazing losses in Panicum maximum cv. Mombaça under four grazing managements. Tropical Grasslands, 40(3), $165 . \quad$ https://assetpdf.scinapse.io/prod/2157114808/2157114808.pdfasse t-pdf.scinapse.io/prod/2157114808/2157114808.pdf

Dospekhov, B. A. (2011). Methodology of Field Experience. Moscow: Al'yans. pp: 33-64. ISBN 978-5-903034-96-3.

Dvořáčková, J., Doležal, P., \& Vyskočil, I. (2013). Effect of the growing season duration of sorghum and Sudan grass hybrids on the chemical composition and digestibility of organic matter. Acta Universitatis Agriculturae et Silviculturae Mendelianae Brunensis, 61(6), 1629-1635. http://dx.doi.org/10.11118/actaun201361061629

Golubinova, I. (2020). Effects of drought stress in genotypes Sorghum vulgare var. technicum [Körn.] by using sucrose in laboratory condition. Bulgarian Journal of Agricultural Science, 26(1), 61-69. https://www.agrojournal.org/26/01-07.pdf

Grigoriev, V. I. (1993). Cultivation of Sudan grass under a modified light regime. Research on Plant Physiology and Biochemistry, 43, 25-27. https://acagor.kz/media/uploads/2019/04/03_\%D0\% A2\%D0\%9E\%D0\%9C_BOOK_COLOR.pdf

Kapustin, S. I. (2019). Cultivation technologies for Sudan grass. FGAOU "North Caucasian Federal University", 3, 25-28. https://www.vetpress.ru/jour/article/view/1040

Kolomiets, N. Y., Gorpinichenko, S. I., \& Ermolina, G. M. (1999). Variety of the Sudan grass 'Stepnyachka'. Corn and Sorghum, 5, 17-18. https://www.elibrary.ru/item.asp?id=24926074 
Kshnyakin, V. A., \& Zozulin, Y. A. (2014). Influence of sowing terms on the yield of Sudan grass in Northern Kulunda. Novosibirsk, pp: 138-144. https://www.vetpress.ru/jour/article/view/1040

Lukhmanova, F. K. (2019). Terms of sowing the Sudan grass. Bashkir NIISH, 1, 15-20. https://www.vetpress.ru/jour/article/view/1040

McIntosh, D. W., Bates, G. E., Keyser, P. D., Allen, F. L., Harper, C. A., Waller, J. C., ... \& Backus, W. M. (2016). Forage harvest timing impact on biomass quality from native warm-season grass mixtures. Agronomy Journal, 108(4), 1524-1530. https://doi.org/10.2134/agronj2015.0560

Mehmet, O. T. E. N. (2017). The effects of different sowing time and harvesting height on hydrocyanic acid content in some silage sorghum (sorghum bicolor 1.) varieties. Turkish Journal of Field Crops, 22(2), 211-217. https://doi:10.17557/tjfc.356224

Nasiyev, B. N. (2014). Innovative techniques in production of fodder protein in adaptive crop science of west Kazakhstan. Life Science Journal, $11(3 \mathrm{~s})$, 150. https://lifesciencesite.com/lsj/life1103s/022_23451li fe1103s14_150_153.pdf

Nasiyev, B., Zhanatalapov, N., Yessenguzhina, A., \& Yeleshev, R. (2019). The use of sudan grass for the production of green fodder, hay and haylage in Western Kazakhstan. Ecology, Environment and Conservation, 25(2), 767-774.

Nazli, R. İ., Kusvuran, A., \& Tansi, V. (2014). Effects of different organic materials on forage production from sorghum $\mathrm{x}$ sudangrass hybrid (Sorghum bicolor $\mathrm{X}$ sorghum bicolor var. sudanense). Türk Tarım ve Doğa Bilimleri Dergisi, 1(Özel Say1-2), 2075-2082. https://dergipark.org.tr/en/pub/turkjans/issue/13311/ 161026
Nichiporovich, A. A. (1961). Photosynthetic plant activity in crops. Izd-vo Akad. nauk SSSR, Moscow, pp: 50-85. https://rusneb.ru/catalog/010003_000061_7570ff20c d6ba90eaf40c7d4c6de6e76/

Raiymbekov, B. A., Orazbayev, S. A., Seitkarimov, A., \& Yancheva, H. G. (2017). Promising species of artemisia in the desert zone of Southern Kazakhstan. Ecology, Environment and Conservation, 23(2), 1195-1201.

Sowiński, J., \& Szydełko, E. (2011). Growth rate and yields of a sorghum-sudangrass hybrid variety grown on a light and a medium-heavy soil as affected by cutting management and seeding rate. Polish Journal of Agronomy, 4, 23-28. http://www.iung.pl/PJA/wydane/4/PJA4_5.pdf

Zanini, G. D., Santos, G. T., Schmitt, D., Padilha, D. A., \& Sbrissia, A. F. (2012). Distribution of stem in the vertical structure of Aruana guineagrass and annual ryegrass pastures subjected to rotational grazing by sheep/Distribuicao de colmo na estrutura vertical de pastos de capim Aruana e azevem anual submetidos a pastejo intermitente por ovinos. Ciência Rural, 42(5), 882-888. https://doi.org/10.1590/S010384782012000500020

Zherukov, B. K., Magomedov, K. G., \& Magomedov, M. K. (2006). Terms of sowing the Sudan grass. Farming, 2, 45-46.

Zhuchenko, A.A., 1990. Adaptive crop growing. Shtiintsa, Chisinau. pp: 350-355, ISBN: 5-376-00834-7.

Ziki, S. J. L., Zeidan, E. M. I., El-Banna, A. Y. A., \& Omar, A. E. A. (2019). Influence of Cutting Date and Nitrogen Fertilizer Levels on Growth, Forage Yield and Quality of Sudan Grass in a Semiarid Environment. International Journal of Agronomy, 2019. https://doi.org/10.1155/2019/6972639 